\title{
NÖVÉNYI MINTÁK FLUORESZCENCIA LECSENGÉSI IDEJÉNEK VIZSGÁLATAI
}

\author{
Lenk Sándor ${ }^{1}$, Sági-Kazár Máté ${ }^{2}$, Illés Levente ${ }^{1}$, Solymosi Katalin ${ }^{3}$, Solti Ádám², Barócsi \\ Attila ${ }^{1}$
}

${ }^{1}$ Budapesti Müszaki és Gazdaságtudományi Egyetem, Atomfizika Tanszék, 1111 Budapest Müegyetem rakpart 3

${ }^{2}$ Eötvös Loránd Tudományegyetem, Növényélettani és Molekuláris Növénybiológiai Tanszék, 1117 Budapest, Pázmány Péter sétány $1 / C$

${ }^{3}$ Eötvös Loránd Tudományegyetem, Növényszervezettani Tanszék, 1117 Budapest, Pázmány Péter sétány $1 / C$

DOI: https://doi.org/10.14232/kvantumelektronika.9.24

\section{Növényélettani bevezető}

A színtestek (vagy plasztiszok) két burokmembránnal határolt és belső membránrendszerrel rendelkező sejtszervecskék, amelyek számos típusa található változatos formában és funkcióval a növények sejtjeiben [1]. Általánosságban a sejt felépítő jellegű (anabolikus), energia-befektetést igénylő anyagcsere-folyamataiban vesznek részt. A zöld növényekben hétféle színtestet szokás elkülöníteni. Ezek közül a legismertebb a fotoszintézis folyamatáért felelős zöld színtest (kloroplasztisz), amely belsejében helyezkedik el a belső burokmembrán befüződéséből kialakult, magányos membrán zsákokból (ún. tilakoidokból) és korongszerüen egymásra rétegződött tilakoidokból álló komplex membránrendszer, amelybe a fotoszintetikus apparátus beágyazódik. Ennek fontos elemei a fénnyel kölcsönható pigment-molekulákat tartalmazó ún. fotorendszerek, valamint a fotoszintézishez szükséges enzimek. A fotorendszeren belül a fény energiájának összegyüjtését végző fénybegyüjtő, valamint továbbításáért felelös antenna molekulákat képező klorofill-molekulák tömegei veszik körbe a reakcióközpontot, ami gerjesztett elektron formájában csapdázza az energiát a további fotokémiai reakciókhoz.

Más színtestektől eltérően a jellemzően kicsi, kezdetleges belső membránnal rendelkező proplasztiszok az osztódószövetekre jellemzőek, és különféle belső és külső fejlődési szignálok hatására belőlük indul fejlődésnek a többi színtest típus. Fény hatására a földfeletti, fotoszintetizáló szövetekben a proplasztiszok kloroplasztisszá alakulnak. Fény hiányában azonban úgynevezett etioplasztiszok differenciálódnak, melyek klorofill-molekulákat egyáltalán nem és a fotoszintézishez szükséges enzimek közül is csak néhányat tartalmaznak [2].

Ez azzal függ össze, hogy a klorofillok bioszintézise a zárvatermő növényekben fényfüggő folyamat, melyet a protoklorofillid-oxidoreduktáz enzim katalizál. Fény hiányában a protoklorofillidklorofillid átalakulás nem megy végbe, klorofillok nem szintetizálódnak, és a fotoszintetikus apparátus felépítésében fontos pigment-protein komplexek a tilakoid-membránokba nem épülhetnek be. Ugyanakkor jellegzetes belső membránrendszerük átrendeződésének köszönhetően megvilágítás hatására az etioplasztiszok gyorsan müködőképes kloroplasztisszá tudnak alakulni.

A fotoszintetikus rendszerek müködése vizsgálatának egyik módja különböző gerjesztési protokollok alkalmazása mellett a fluoreszcencia válaszjel regisztrálása, majd ebből leggyakrabban arányszámok segítségével a fotokémiai és nem fotokémiai kvantumhatásfokok becslése. Az egyik leggyakrabban 
használt mérési protokoll az impulzus amplitúdó modulált (PAM, pulse amplitude modulation) technika [3]. Ennek során a minta fénykörnyezetét állandó, fotoszintetikusan aktív ('aktinikus') megvilágítással, valamint nagy ('telítő') fényimpulzusokkal több nagyságrend dinamikával változtatjuk, melynek hatását egy állandó, de kis fotonszámú, adott (kHz-MHz) frekvenciájú mérőjelre kapott, a méröjel periódusánál nagyobb $(\mu \mathrm{s}-\mathrm{ms})$ időállandókat felbontani képes változó fluoreszcencia válasz formájában detektáljuk. A módszer segítségével a fotorendszereket igen eltérő növényfiziológiai állapotban tesztelhetjük, ami lehetőséget biztosít arra, hogy a fotokémiai és nem fotokémiai fényhasznosításról megállapításokat tegyünk. A módszer hátránya az, hogy például a fluoreszcencia-jel csökkenéssel válaszolhat a fluoróforok számának csökkenésére és egy megnövekedett alternatív energiafelhasználási (kioltási) mechanizmusra egyaránt [4]. Egy másik fluoreszcencia alapú méréstechnika - a fluoreszcencia lecsengési idők vizsgálata - segíthet a különböző állapotú müködőképes rendszerekben különbséget tenni.

A fluoreszcencia lecsengési idők mérésénél ugyanis nagy (néhány $10 \mathrm{MHz}$ ) ismétlési frekvenciával rövid - ideális esetben - Dirac-delta-szerü gerjesztést adunk a vizsgált mintára és az erre érkező fluoreszcencia válaszjelet nagy időfelbontással regisztráljuk. A mérésünk eredménye a Diracimpulzust követő fluoreszcencia jel intenzitásának csökkenése. Ez az intenzitás-csökkenés függ az adott anyagra és azt körülvevő közegre jellemző természetes fluoreszcencia élettartamtól, valamint a nem-sugárzásos átmeneti mechanizmusok kioltási rátájától.

\section{Méréstechnikai alapok és eszközök}

A fluoreszcencia lecsengési idők többnyire a 'ns', vagy az alatti időtartományba esnek. Vizsgálatukhoz így a mérni kívánt lecsengési időknél rövidebb impulzusokat szolgáltató gerjesztő forrásokra van szükség. A megoldást esetünkben az LDH-P-C-650 (PicoQuant) szálba csatolt lézerdióda jelenti, amely adott lézerteljesítmény kimenet esetén $\tau_{\mathrm{FWHM}}<100$ ps hosszú impulzusokat szolgáltat. A mérni kívánt fluoreszcencia lecsengési időállandók hasonlóak ehhez az impulzushosszhoz, amihez $10 \mathrm{ps}$ vagy az alatti időfelbontás szükséges. Ilyen időfelbontásra az időkorrelált egyfoton detektálás (Time Correlated Single Photon Counting - TCSPC) az egyik elfogadott megoldás. A módszer lényege, hogy a mintát $10 \mathrm{MHz}$ nagyságrendü ismétlődési frekvenciával fényimpulzusokkal gerjesztjük és mérjük a gerjesztés és mintából jövő első foton között eltelt időt. A feldolgozó rendszer a gyakorlatban nagyszámú (esetünkben $2^{16}$ ) időcsatornát kezel, melyek időintervalluma rövid (esetünkben akár 4 ps is lehet). Minden sikeresen detektált fotonnál valamelyik időcsatorna értéke +1-gyel növekszik. A mérés eredménye detektálási gyakoriság az eltelt idő függvényében. Vagyis több stopperóra-szerü mérést felösszegezve határozzuk meg a fluoreszcencia élettartamát. A mért eredmények a gyakorlatban általában egy vagy több exponenciális függvény összegeként írhatók le. Kísérletünkben MPD-100-CTB (PicoQuant) egyfoton detektort használtunk PicoHarp 300 (PicoQuant) TCSPC elektronikával. A mérési elrendezést az 1. ábra mutatja.

Megjegyzendő, hogy egy (általunk itt nem alkalmazott) alternatív módszer a fluoreszcencia élettartam vizsgálatára egyrészt a fázisérzékeny detektálás alkalmazása, amikor a mintát modulált fénnyel gerjesztve az időállandókat a fázisban eltolt és amplitúdóban modulált fluoreszcencia-jelből számoljuk. Másrészt további lehetőség a molekuláris folyamatok direkt vizsgálatára a lecsengési idők ultrafinom felbontása femtoszekundumos spektroszkópiával. 


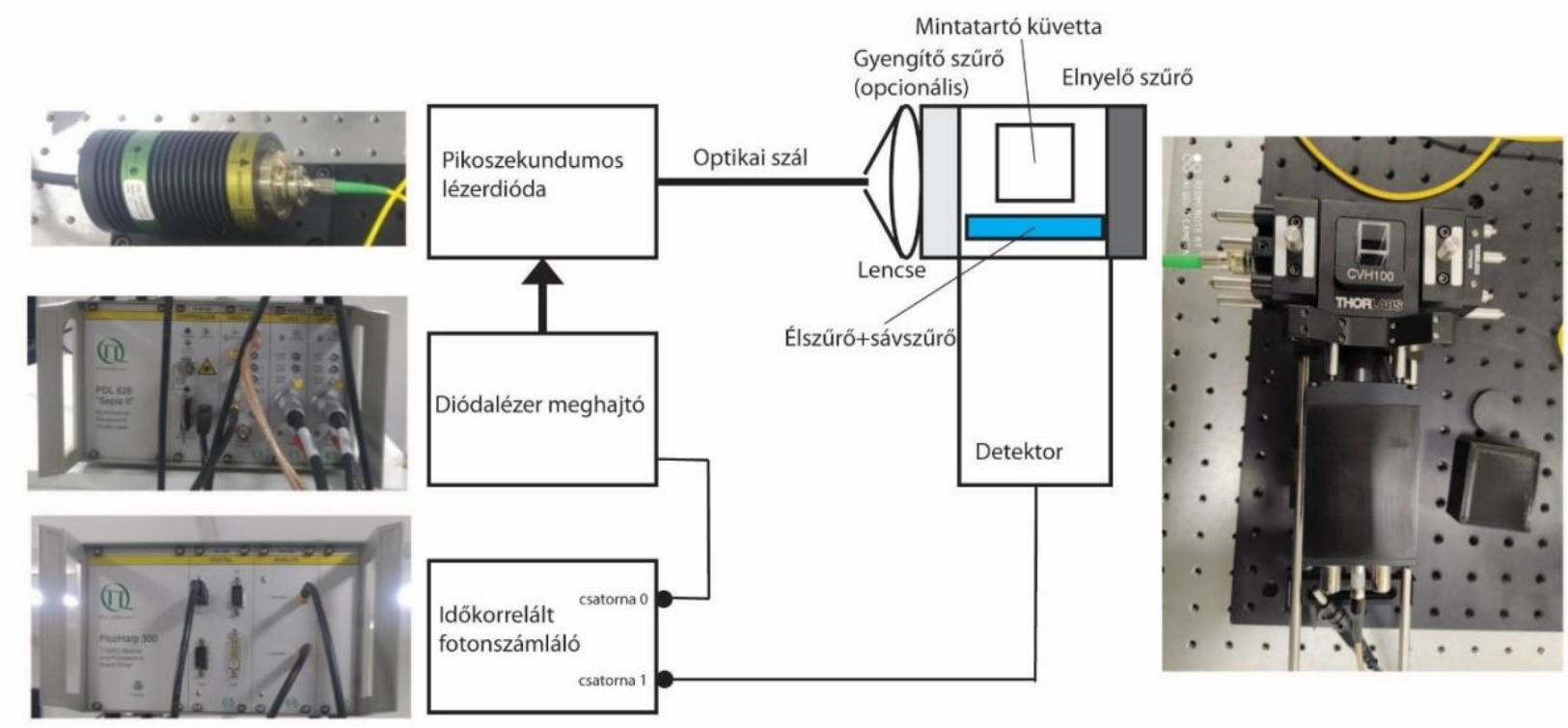

1. ábra

A megvalósított mérési elrendezés sematikus ábrája kiegészítve a főbb elemekröl készült fotókkal.

A diódalézerünk fénye egy kollimátor lencsével ellátott optikai szálon keresztül jut a mintartóba. A diódalézer impulzushossza a lézerteljesítmény függvényében változik. Az impulzushossz és alak optimumát az elérhető maximális fényintenzitás 50\%-ánál találtuk. Az időkorrelált méréstechnika sajátossága, hogy legfeljebb a gerjesztő fotonok 5\%-áról detektálhatunk emittált fluoreszcenciát. Ha ennél gyakrabban érkezik fluoreszcencia-foton a detektorra, akkor az a mérés szisztematikus hibáját eredményezi az úgynevezett 'pile-up' (felhalmozódás) jelenségén keresztül. Erősen fluoreszkáló mintáknál így a gerjesztő fény csökkentésére lehet szükség, amely lehetőségre a mérési elrendezésbe egy gyengítö szüröt terveztünk. A detektorba a fluoreszencia fényen kívül a gerjesztő jel is beszóródhat. A (655 nm-es) gerjesztő és a mérni kívánt ( 690-750 nm tartományba eső) fluoreszcencia jeleket spektrálisan optikai szürőkkel választjuk szét. Kevéssé fluoreszkáló mintáknál a fluoreszcencia fény akár több nagyságrenddel kisebb lehet a gerjesztő forrás szórt fényénél. Ezért egy optikai élszürő (Thorlabs FGB25) és egy sávszürő (Semrock 708/75) kombinált alkalmazására van szükség.

\section{Elözetes eredmények}

A kísérleti összeállításunkat fejeskáposztából (Brassica oleracea convar. capitata var. alba, 2. ábra bal oldala) izolált, fotoszintetikus müködésre kész kloroplasztiszokkal, valamint gátolt müködésü izolált etioplasztiszokkal (2. ábra jobb oldala), és fotoszintetikus müködést nem mutató, acetonban oldott klorofill oldattal teszteltük. 

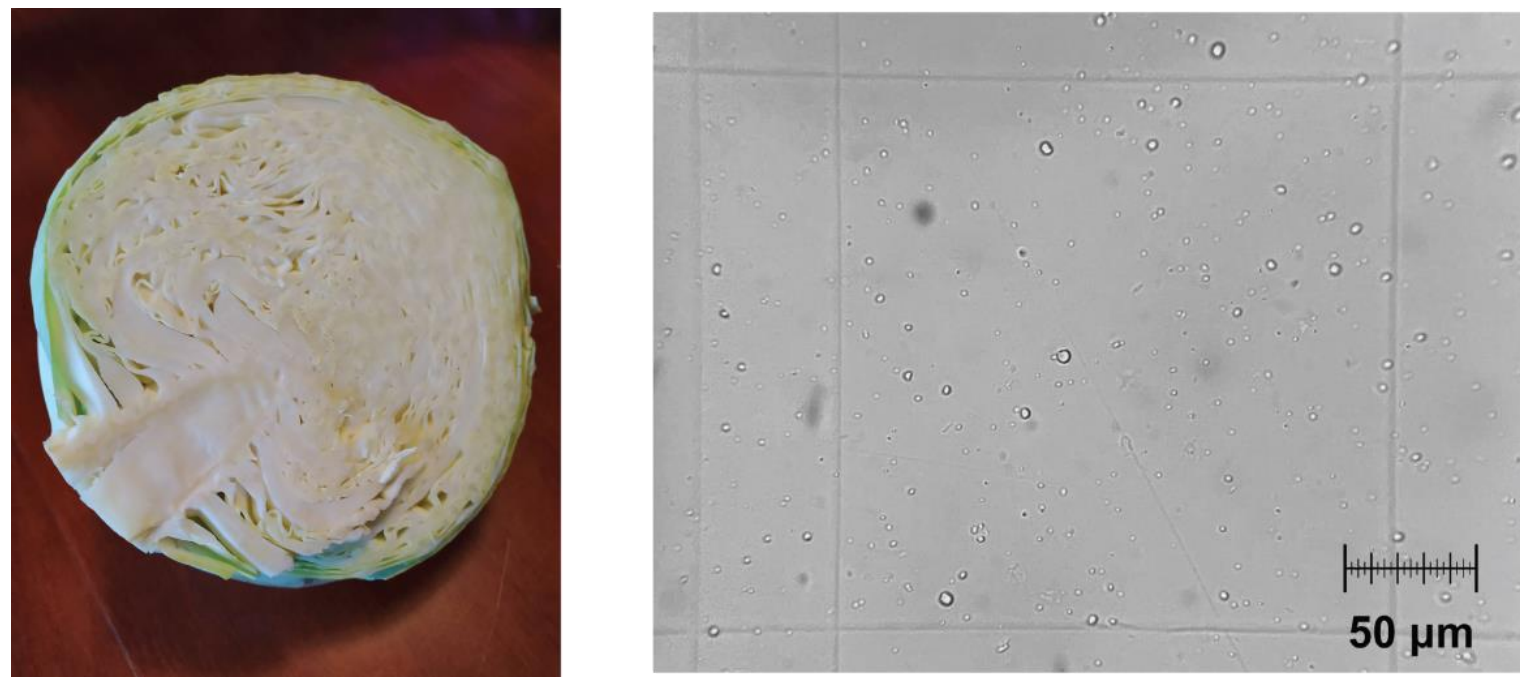

\section{2. ábra}

Bal oldalt: fotó egy fejes káposztáról az izolálás megkezdése előtt, jobb oldalt: optikai mikroszkópos felvétel fejeskáposztából izolált etioplasztiszokról

A 3. ábrán a mért fluoreszcencia lecsengési időket egyre normálva, lineáris skálán mutatjuk be, a mérési eredmények a vártnak megfelelő eredményt szolgáltattak. A kloroplasztiszoknál a fényenergia igen jelentős részben fotokémiai úton hasznosul, ami miatt a fluoreszcencia lecsengési idő lerövidül. Ezzel szemben a korlátozott fotoszintetikus müködésü etioplasztisznál a fluoreszcencia lecsengési idő lényegesen hosszabb, míg a fotoszintetikus müködést nem mutató acetonban oldott klorofill mintánál a leghosszabb. Az etioplasztisz mintánál szükséges mérési idő lényegesen nagyobb volt és a jel/zaj viszony is rosszabbnak bizonyult. Ennek oka részben az etioplasztisz minta kisebb organellum száma, jóval alacsonyabb pigmenttartalma lehetett.

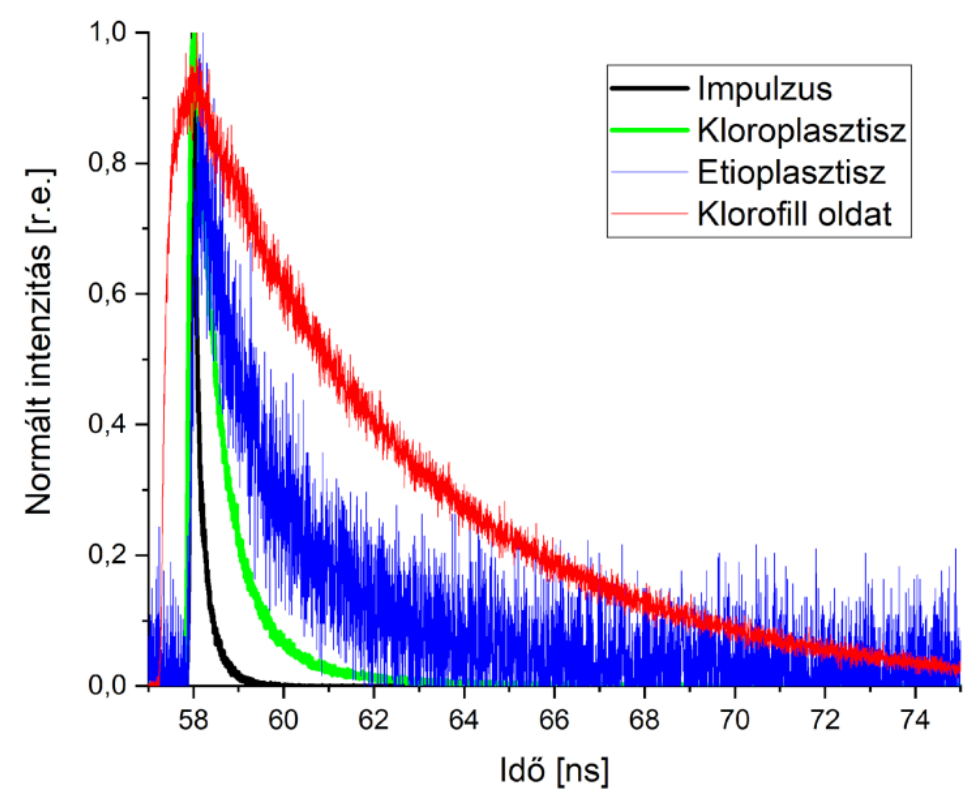

3. ábra

A készülék válasz függvény (fekete), a mért fluoreszcencia lecsengési ideje egy kloroplasztisz mintának (zöld), egy etioplasztisz mintának (kék) és egy klorofill oldatnak (piros) 


\section{4. Összefoglalás}

Mérési elrendezést hoztunk létre folyadékban elegyített, $655 \mathrm{~nm}$-en gerjeszthető növényi minták fluoreszcencia lecsengési idejének vizsgálatára. Kísérleteket kezdtünk különböző fotoszintetikus müködést mutató növényi mintákkal. Az optimális fotoszintetikus müködést mutató kloroplasztiszoknál rövidebb, míg a fotoszintetikusan nem aktív etioplasztiszoknál hosszabb fluoreszcencia lecsengési időket találtunk.

\section{Köszönetnyilvánítás}

A kutatást a Nemzeti Kutatási Fejlesztési és Innovációs Alap támogatta a Nemzeti Kiválósági Program keretében, a "Kvantumbitek előállítása, megosztása és kvantuminformációs hálózatok fejlesztése" címü, 2017-1.2.1-NKP-2017-00001. számú projekt részeként, valamint az Új Nemzeti Kiválósági Program keretében, az "Etioplasztiszok vastranszport mechanizmusainak molekuláris vizsgálata” címü, ÚNKP-20-3-I-ELTE-862 azonosítójú projekt részeként.

\section{Irodalom}

[1] R.R. Wise, "Plastids: The Anabolic Factories of Plant Cells", in: R.A. Bradshaw and P.D. Stahl (eds.), Encyclopedia of Cell Biology, 2, 324-330, (Waltham, MA: Academic Press, 2016) https://doi.org/10.1016/B978-0-12-394447-4.20030-8

[2] R.D. Willows, „Chlorophyll synthesis”, in: R.R. Wise and J.K. Hoober (eds.), The Structure and Function of Plastids, pp. 295-313, (Amsterdam: Springer, 2006) https://doi.org/10.1007/978-1-4020-4061-0

[3] U. Schreiber, U. Schliwa and W. Bilger Continuous recording of photochemical and nonphotochemical chlorophyll fluorescence quenching with a new type of modulation fluorimeter Photosynth. Res. 10, 51-62 (1986) https://doi.org/10.1007/BF00024185

[4] J. Zaks, K. Amarnath, E. J. Sylak-Glassman, G. R. Fleming Models and measurements of energydependent quenching Photosynth. Res. 116, 389-409 (2013)

https://doi.org/10.1007/s11120-013-9857-7 